\title{
Perceived Improvement of Mangrove Forest Among Gorap People in Bobaneigo Bay
}

\author{
Safrudin Amin ${ }^{1, *}$

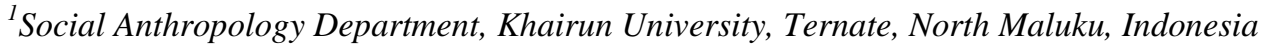 \\ *Corresponding author. Email: safrudin@gmail.com
}

\begin{abstract}
Research on coastal natural resources has confirmed that mangrove plays crucial roles in coastal ecosystems both ecological and sociocultural. Although its critical roles, other studies also release gloomy pictures of mangrove destruction which have a damaging impact on coastal life. Different from many previous studies on the roles of mangrove and the impact or potential impacts of its destruction, this paper focuses on exploring how the local people view their environmental changes, particularly mangrove forests, and how they interpret the causes and the impact of the changes. By employing an ethnographic method, this study finds that local people in Bobaneigo Bay perceive a significant improvement of mangrove forests stretching along part of the coastline of the bay for the last fifteen years. They develop knowledge, mixing local and supra-local knowledge, to make sense of the causes and impact of the perceived changes of the coastal natural resources. The findings can contribute to an anthropological discourse on the dynamics of relationships between human and natural resources and how humans construct the dynamics socioculturally.
\end{abstract}

Keywords: perception, mangrove, improvement, Bobaneigo Bay, local knowledge, natural resources

\section{INTRODUCTION}

This study explores the sociocultural dimension of environmental resources, especially mangroves. This article explores how the people of Bobaneigo Village interpret changes in the mangrove forest. Acting of interpreting and responds to the environment has been one of the anthropological interests in anthropological theories and ethnographies. This study, therefore, is part of the anthropological project in studying human interactions with their environment, specifically related to the mangrove.

In general, studies on mangroves have been carried out by various parties dealing with diverse issues ranging from studies relating to ecological, economic, and socio-cultural aspects. In general, previous studies have one in common that mangrove has many benefits. Among these benefits are mangrove can become building materials, firewood, medicines, ecological benefits for the coastal environment, and it can play an important role in reducing emissions. Indonesia has committed to reducing emissions by $26-$ $41 \%$ in 2020 .

Although it has many benefits, many reports reveal undergoing widespread deforestation in mangroves in the last few decades. In Southeast Asia, from 2000 to 2012 there was deforestation of more than 100,000 hectares of mangroves [1]. In Indonesia data from various sources published in 1996 to 1997 regarding the area of mangrove forests varies greatly, but the estimation is around 2.49 to 4.54 million hectares. The existing mangrove forest could even be less than that because in the late 1980s Indonesia only had 2.49 million hectares. This means that the country has lost about $40 \%$ of its mangrove forest area in that period [2]. Other estimates believe that Indonesia's mangrove areas were degraded from 4.2 million in 1980 to 3.1 million in 2011 [3].

Apart from the gloomy pictures of mangrove forests both on a global and national scale, it is important to see other optimistic development on mangrove forests in Indonesia. Growing awareness about the importance of mangroves for natural and human ecosystems causes mangrove deforestation becomes a concern in various parts of the world. Based on these concerns, efforts have emerged to safeguard existing mangrove forests or restore damaged mangrove forests.

The Government of Indonesia, for example, until the year 2008 through the Ministry of Forestry had rehabilitated mangrove areas amounting to 37,539 ha. The Ministry of Forestry also planned to continue mangrove rehabilitation at about 15,000 ha in 2013 through the programs of Land Forest Rehabilitation, People Nursery and Social Aid [4] (Kusmana, 204: 57). Several other studies reveal that the improvement of mangrove forests is not only driven by government policies but there is also reforestation of mangrove coming from community initiatives in certain localities which are then supported by government policies [5] (Sugiana, 2011). Other studies show that the improvement of mangrove forests occurs due to the application of unwritten rules and local wisdom at the community level which ultimately leads to the improvement of mangrove forests [6] [7] (Basyuni et al, 2016; Iwasaki and Rahman, 2017).

Thus far studies on improving mangrove forests, as shown earlier, have revealed improvements to mangrove forests 
because it was planned both by the government through rehabilitation policies and by community groups through community initiative with or without supports by government or non-governmental organizations. Unlike the previous research mentioned earlier, this article reveals an improvement of mangrove forests as unintended consequences as a result of the development of other factors in the environment and on the community itself. This study was conducted in Bobaneigo Village, West Halmahera Regency, Indonesia. From the fieldwork data, it was revealed that there was a strong view of the villagers that the mangrove forest in Bobaneigo Bay in the past until 1960 was very dense. This condition began to erode gradually from the late 1970 s to the 1990 s as the village population grew faster and the widespread use of mangrove as a source of firewood. According to them at the present the mangrove forest in the Bobaneigo bay is much better although not similar to the conditions of the 1960s. This is especially evident from the regrowth of mangroves along the coast which were once suffered damage. The task of this article is to uncover the emic perspective of Bobaneigo villagers on the causes of the improved mangrove forest in Bobaneigo Bay.

\section{METHODS}

\section{A. Location and Sample}

This study was based on a fieldwork conducted in Bobaneigo Village in Halmahera. This study employs qualitative ethnography method. During the fieldwork, 20 villagers were chosen purposefully as key informants.

\section{B. Duration, Data Collection and Data Analysis}

This ethnographic uses two data collection techniques: interview and observation. The fieldwork has begun in 2014 and continued intermittently until 2019. Therefore, some information presented here were derived from data collected in 2014. Data analysis is conducted based on Miles and Huberman's proposal which includes data reduction models, data presentation, and drawing conclusions [8].

\section{RESULTS AND DISCUSSION}

In the eyes of local people, the mangroves in the bay are getting better lately. Field data shows that in the cognition system of Bobaneigo community, there are two main factors that have caused mangrove forests to improve in the last 15 to 20 years. The two reasons include switching their firewood sources from mangroves to wood from forests or gardens and the reappearance of crocodiles to the Bobaneigo bay.

\section{A. Transition from Mangroves to Firewood from the Forest.}

In the 1970s until the late 1980s the price of cloves boomed (the price of cloves was good enough at that time) so that the villagers of Bobaneigo began to explore forests further to the south direction from the village. The distance between the location of the garden and the village is getting further away and the community also needs a feasible road that connects the garden and village. To meet this need, since about the 1990s the community opened a road connecting their plantation areas to the village of Bobaneigo. They developed a road they called 'jalan tani' which literally means 'peasant road'. The road was then strengthened by the support of logging companies (some also called government support) so the road was widened and extended using a bulldozer. The length of this road is around $5.5 \mathrm{~km}$ from their original gardens. The road can also be passed by a truck.

At the same time several people had owned trucks since the mid-1980s for transporting passengers and goods from Bobaneigo to the port of Dodinga and vice versa. Dodingan is a village on the West lip of Halmahera that faces the island of Ternate. Some residents have additional work as wood and board makers in the forest. Their wood production, in the past, was transported to the village by means of carrying on their shoulder or using carts pulled by cows. Since the existence of trucks, they have begun to use the services of trucks that are more efficient and can transport more.

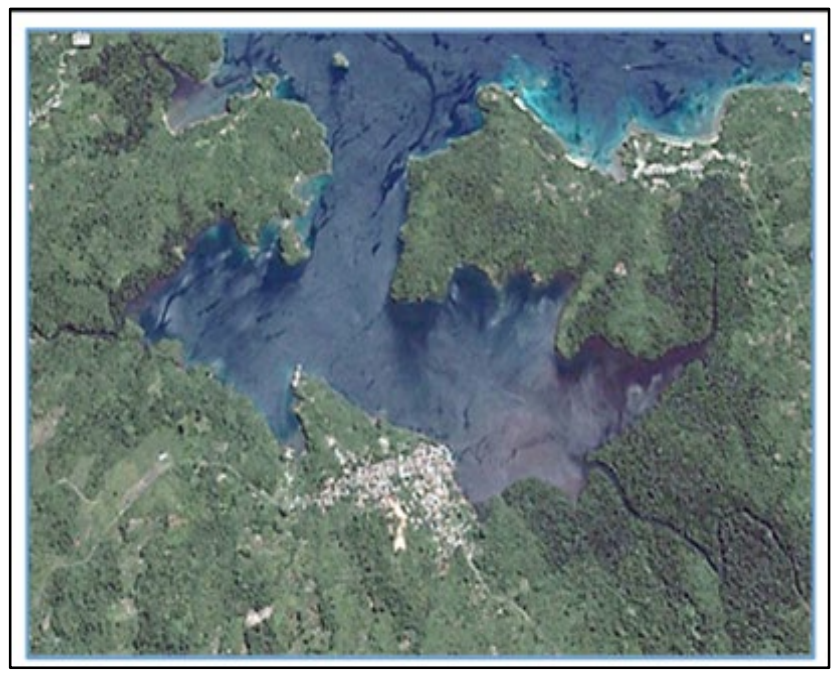

Figure 1. Bobaneigo in Teluk Bobaneigo

Since then, taking firewood from the forest, according to the community, is much easier due to the existence of the truck roads to and from forests and gardens than before the roads and trucks available. Previously they only took firewood from the forest in small amounts and generally only the fallen branches of dried trees because of the difficulty of carrying firewood from the forest in large quantities. That is why in the past it was easier to take mangroves as firewood because they could be pulled by boat by sea. Now people prefer to take firewood in the forests around their gardens because it is easier and can be taken in more quantities. They can cut down trees, or cut fallen trees, divide them into smaller pieces, put them on the side of the road, then contact the truck to get them home. 
Due to the availability of roads and vehicle to the garden and forest, access to the source of firewood in the garden and forest become much easier. This is also supported by the familiarity of wood cutting sensor machines that replace the use of axes, introduced by several logging companies in this area in the 1970s to 1980s. This machine makes it easy to cut wood for firewood and wood for building equipment in large quantities. Since then the villagers have begun to shift to collect firewood from the forest and from their gardens, leaving behind the habit of taking mangroves as firewood. The shift from mangroves to firewood from the forest, according to informants, has allowed mangroves in the bay to grow and begin to thrive again.

\section{B. The Return of Crocodile}

In addition to the community's shift from mangrove to firewood from the forest, according to several informants, the improvement of mangrove forests is also caused by the fear of taking mangroves on the beach because of the appearance of crocodiles in the Bobaneigo bay. Actually the phenomenon of the appearance of crocodiles in the bay of Bobaneigo only occurred about the last 10 years. Initially only in the form of stories of some people who said they saw a crocodile but were not widely trusted. From time to time the story becomes a public discourse in the village because more and more people claim to have seen a crocodile on the village's shore. In 2014, some people led by Mr. Idrus Hi Ali made a snare to catch a crocodile. He managed successfully to catch a big crocodile. The community pulled it to the mainland and tied him to death in an empty building. The community claimed that they were increasingly convinced of the threat of crocodiles in the bay.

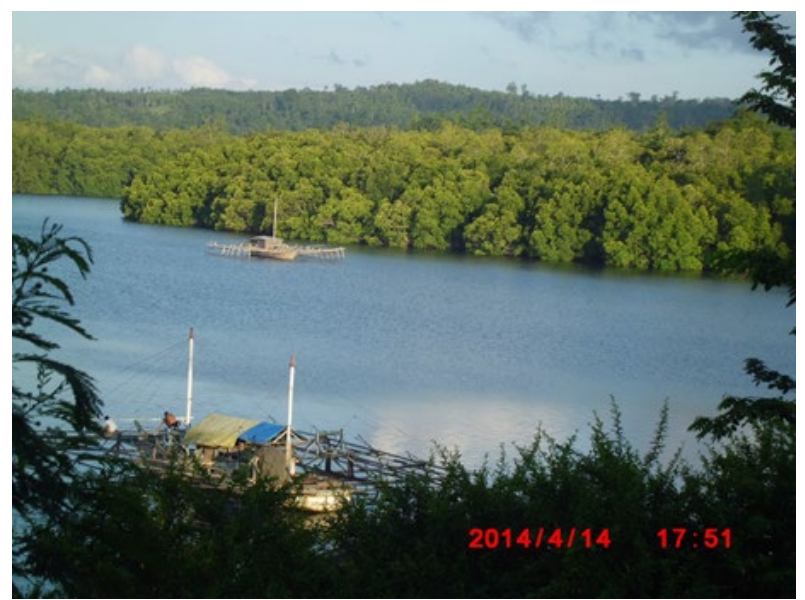

Figure 2. Condition of mangrove forests in 2014 in the Ngengeluku area, Bobaneigo Bay.

The villagers' fear of the threat of crocodiles is not without reason. In the past, one of Bobaneigo's ancestors was pounced on by a crocodile in the area of Domen, the biggest muddy river filled with mangrove trees. They call the victim as 'nene maka-maka buaya' meaning a grandmother who was eaten by a crocodile. This story is hereditary in the village. Until the 1950s Bobaneigo Bay became one of the ecosystems inhabited by many crocodiles. In that period the crocodile skin trade was luxurious and quite tempting. Probably because of that reason, some Bobaneigo people participated in crocodile catching activities in Bobaneigo Bay led by two people from Kendari, Southeast Sulawesi.

Informants believe the crocodile catching activity had killed all the crocodiles in the bay. Since then, it had never been heard of anyone finding a crocodile in the bay. What even developed was a mythical story about the ancestral sacred crocodile of one of the Bobaneigo clans who inhabited the mouth of the Domen river, the largest river among all rivers in the bay. This sacred crocodile are believed to have a crown on his head and would protect the descendants of the clan who own him. The sacred crocodile, however, seems just merely a myth since it was never seen by residents.

So why did a crocodile appear in the 2000 s. One version of the dominant explanation is that the new crocodile came from other parts of Kao Bay, especially in several large rivers near the gold mining company NHM (Nusa Halmahera Mineral). For this view, the crocodiles cannot survive sea water pollution due to company waste so they migrate to the end of the Kao bay, the Bobaneigo Bay. They are not the sacred crocodile as believed by some people.

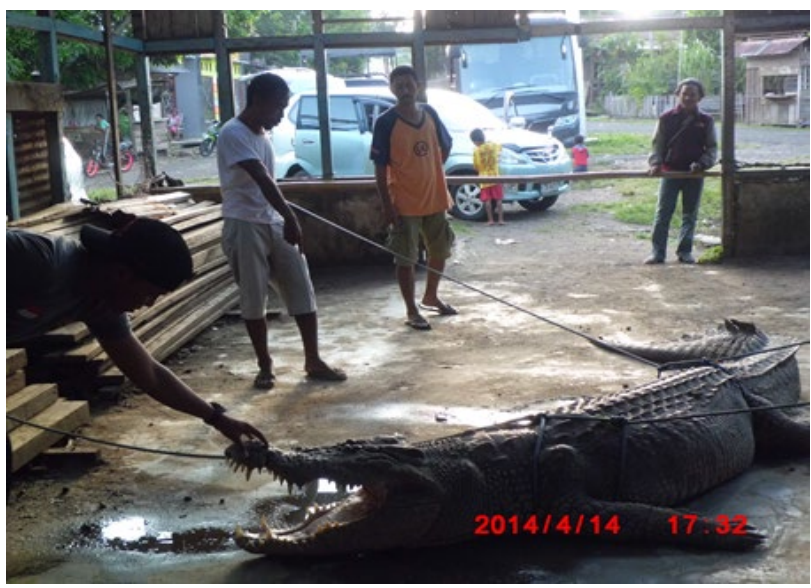

Figure 3. Crocodile captured by Idrus in 2014 in Bobaneigo beach.

For the Bobaneigo community, the reappearance of crocodiles in the bay strengthens their decision to stop using mangroves as firewood because it is believed that crocodiles often hide in mangrove ecosystems. Some informants explicitly said that people are afraid to take mangroves because they are afraid of crocodiles.

\section{CONCLUSION}

This article reveals improvements in mangrove forests in the subjective perception of local communities. This article has shown that the improvement of mangrove forests is not only due to serious planned efforts by both the government 
and the community, as has been generally revealed in previous studies. This article presents the fact that the improvement of mangrove forests can also be caused by unplanned changes. It is found in the case of mangrove in Bobaneigo bay that the improvement of mangrove is the result of socio-cultural and environmental changes that are not directly related to mangrove forests but have a positive impact on the survival of mangrove forests.

\section{ACKNOWLEDGMENT}

Although this study is a fully self-funded research, in some extent I have got support from faculty of culture and research unit of Khairun University. Therefore, I would like to thank to the dean and the head of the research unit for their official supports. I also would like to thank to the informants who have spent time to answer my various questions and guided me to the mangrove forest in the coastal of Bobaneigo bay.

\section{REFERENCES}

[1] National University of Singapore. 2016. "Causes of mangrove deforestation in Southeast Asia identified." ScienceDaily. ScienceDaily, 5 January 2016.

$<$ www.sciencedaily.com/releases/2016/01/1601051 01853.htm>.

[2] R. Noor, Y., M. Khazali, and I N.N. Suryadiputra. 1999. Panduan Pengenalan Mangrove di Indonesia. PHKA/WI-IP, Bogor.

[3] Giri, C. at el., 2011., "Status and distribution of mangrove forests of the world using earth observation satellite data," Global Ecology and Biogeography., vol. 20, pp. 154-159.

[4] C. Kusmana, 2014. "Distribution and Current Status of Mangrove Forest in Indonesia" in Mangrove Ecosystems of Asia: Status, Challenges and Management Strategies. I. Faridah-Hanum, A. Latiff Khalid Rehman Hakeem, Munir Ozturk (eds). Springer: New York.

[5] A. M. Sugiana, 2011. Community Dynamics and Ecological Sensibility for Sustainable Mangrove Governance in Sinjai Regency, South Sulawesi, Indonesia Asian Journal of Agriculture and Development, Vol. 9, No. 2. p. 77-98.

[6] M. Basyuni, R. A Rouf, M. Saragih, A. M Asbi, W. Yuriswan, 2016. Local Wisdom and Mitigation Action to Maintain Secondary Mangrove Forest: A Case Study of Jaring Halus Village in Langkat, North Sumatra, Indonesia. Advances in Social Science, Education and Humanities Research (ASSEHR), volume 81, 1st International Conference on Social and Political Development (ICOSOP 2016).

[7] S. Iwasaki and A. Rahman, 2017. "Roles of Traditional Coastal Management Institution for Mangrove Rehabilitation and Restoration in Aceh Province, Indonesia" in Participatory Mangrove Management in a Changing Climate: Perspectives from the Asia-Pacific. Rajarshi DasGupta and Rajib Shaw (eds). Tokyo: Springer.

[8] M. B. Miles, and A. M. Huberman. Analisis Data Kualitatif. Jakarta: UI-Press, 2005. 